\title{
8 A just mining framework for the ethics of extraction of natural resources and integral peace
}

\author{
Tobias Winright
}

\section{Introduction: from law enforcement and the use of force to mining}

Although I am a Catholic ethicist and theologian, I previously worked as a law enforcement officer, in corrections and policing, and much of my scholarly and popular writing addresses the ethics of the use of force (Winright 2020). This book considers mining and conflict. A synonym for mining is extracting, which evokes memories of when I occasionally was part of an extraction team, tasked with extracting an obstinate, bellicose inmate from his cell in a maximum-security jail. If the team's presence at the cell's doorway and our verbal directions failed to persuade him to come out peacefully, then we had to enter the cell and escort him out. Sometimes doing so required the use of force, depending on the inmate's level of resistance: it might have sufficed to handcuff him and hold his arm as we accompanied him from the cell, or it might have entailed carrying him out while he was restrained in a wheelchair-and if the prisoner attempted to punch, kick, or bite us, then self-defense techniques would be employed, such as controlling holds involving pressure points. "Extraction" is "the action of taking out something (especially using effort or force)" (Vocabulary.com n.d.). The words "taking out something" reminds me, moreover, of when police refer to "taking out someone" (that is, subduing or shooting them) when, for instance, a suspect is on the verge of murdering an innocent hostage. Other synonyms for "extracting" include: removing, seizing, dislodging, pulling, coercing, prying, compelling, uprooting, wresting, wringing, displacing, and mining. These all involve the use of force, which is often associated with conflict.

Not all conflict, of course, involves the use of armed force or even violence. After all, as John Paul Lederach (2003) observes, "conflict is normal in human relationships, and conflict is a motor of change" (5); it is, in other similarly positive words, "a natural phenomenon that creates potential for constructive growth" (15). Still, conflict often holds a more negative connotation-that is, when it pertains to the use of force, 
violence, war, destruction, and death. In such conflict, the use of force, whether in self-defense, policing, or war, bears a burden of proof before it can be regarded as morally just. In the words of the United States Catholic bishops, in their 1983 pastoral letter The Challenge of Peace, our starting point is a "presumption against the use of force" $(\mathbb{1 2 0})$. In the Catholic theological tradition, this moral stance or orientation concerning the use of force gave rise to the development of just war theory. ${ }^{1}$ As the primary framework for moral reasoning about the use of force, just war theory traditionally has included two categories of criteria or principles: jus ad bellum includes criteria that justify going to war; and jus in bello includes principles for the just conduct of war. In recent years, a third category has also gained traction: jus post bellum includes principles and practices for the promotion and protection of a just and lasting peace after a war ends (Allman and Winright 2010).

Writing about natural resource extraction, which "endangers both the environment and peace," and the need for "sustainable mining" in South Africa, Peter Knox (2015) admits that this entire enterprise is "a concept in search of a theory" (117). Similarly, in an article on "The Missing Ethics of Mining," Shefa Siegel (2013) laments that "we are ready to discuss almost any other ethics before the ethics of mining," and asserts that "we have more faith in our capacity to restrain or end violence and war than to address the ethics of mining" (n.p.). Although Siegel seems correct about the amount of attention given to the ethics of violence and war in comparison to the ethics of mining, I question whether such deliberation necessarily must be conducted in an either/or, uncoupled fashion. Indeed, to examine extraction ethics, I suggest that we do not have to start from scratch: that the ethics of war may be applicable in an analogous way to the ethics of extraction, since both these activities involve the use of force. William P. George (2019), in his book Mining Morality: Prospecting for Ethics in a Wounded World, similarly suggests-without pursuing and developing it himself-that "the ethics of mining and the ethics of war, especially nuclear war, might be joined" (18). This is the task that I pursue in this chapter.

In what follows, I offer an exercise in what Lederach (2005) calls "moral imagination," a creative effort "to perceive things beyond and at a deeper level than what initially meets the eye" (26-27). Beneath the surface, the ethics of extraction, I reckon, is related to the ethics of the use of force as exhibited in just war theory. In the words of Lloyd Steffen (2012), there is "a way of ethical thinking," an "ethic that lies behind just war" that should be "widely applicable to all kinds of ethical issues," including but going "beyond the particular question of war or the use of force" (15, italics original). Although Steffen does not consider it, I suggest that this is the case for the morality of mining. Over the years, I have similarly addressed moral issues in law enforcement, inspired by Edward A. Malloy's (1982) invitation to ethicists to undertake an imaginative "exercise of 
analogical interpretation" using the reasoning and principles of just war theory to address police use of force (24). Accordingly, in this chapter I propose an ethics of extraction that includes a just mining theory with moral criteria encompassed under three categories: jus ad extractionem, jus in extractione, and jus post extractionem. This ethics of extraction, moreover, is meant to speak accessibly to government and corporate decision-makers, regardless of whether they share the Catholic faith and theological beliefs of the contributors to this volume. In doing so, it exemplifies what James M. Gustafson $(1988,1996)$, in his identification of four modes of moral discourse, refers to as ethical and policy discourse, rather than prophetic and narrative discourse. At the same time, I believe this proposal is coherent with a Catholic "integral peace" approach to addressing mining and conflict.

The chapter proceeds in four steps. In the first, the link between mining and conflict, between extraction and the use of force, is substantiated through attention to several cases. In the second, the ethic behind just war, which informs and suffuses just war thinking, is articulated as well as illustrated through its application to other moral issues. In the third, an ethics of extraction is constructed with a just mining theory comprised of three categories of criteria. In the fourth and concluding section, Gustafson's moral modes of ethical discourse are delineated to demonstrate how this chapter contributes to the development of a Catholic integral peace approach to addressing mining and conflict.

\section{Mining and conflict: the use of force in mining}

There are multiple ways mining and conflict are related. One under consideration within this present volume is the frequent correlation between mining and armed conflict. The so-called "resource wars," which are a part of wider "environmental conflict," occur between, or within, nations about scarce, finite natural resources (Detraz 2015). Mining sometimes is a driver of armed conflict, or perhaps more specifically, asymmetric natural resource wars. Rigobert Minani's chapter in this book describes how mining of materials like coltan and gold in the DRC is connected to violent conflict and profits for rebel groups (see also Koch and Kinsbergen 2018). Indeed, rebel groups, upon acquiring access to these resources within a conflict zone, are more able to finance their efforts against government military and police forces (Lujala 2010; Lee 2018). Similarly, Karl Gaspar's chapter notes how armed groups in the Philippines profit from mining indirectly by extorting mining companies. Of course, on the other hand, military, police, and paramilitaries, as well as mining corporations' own security forces, sometimes use force and employ violence not only against rebel groups but also indigenous communities. In Honduras, Bishop Santos Villeda (2018) describes how, through their funding of the government, foreign gold mining companies "subdue people by means of the armed forces, destroying 
churches and entire villages, even removing the dead from cemeteries in order to obtain the gold found in those areas" (93). In South Africa, labor disputes can lead to the loss of life, such as when police shot and killed thirty-four striking miners on August 16, 2012, at Lonmin's platinum mine in the town of Marikana (Knox 2015, 125). Andrés McKinley describes "aggressive street demonstrations" led by the Canadian mining company Pacific Rim against the Archbishop of San Salvador and others seeking to ban metallic mining in El Salvador at about the same time that five antimining activists were assassinated in Cabañas, where Pacific Rim was insisting, "at all costs," on mining gold and silver. And in this book, the chapters on Peru by Derechos Humanos y Medio Ambiente-Puno, and on Colombia by Héctor Fabio Henao and Sandra Polanía-Reyes, note instances of human rights and environmental defenders being targeted for intimidation and assassination.

In addition to actual armed conflict, the relationship between mining and conflict surfaces when we consider the negative, harmful consequences of mineral extraction itself on the environment and on people and communities. Put differently, mining inflicts violence on nature as well as on humans who are involved with, or impacted by, mineral extraction activities. As one environmental scientist notes, life-cycle assessments of metals that are commonly used in jewelry and technology reveal that gold and the platinum-group metals yield the greatest environmental burdens among metals, "as measured by cumulative energy use, global warming potential, human health implications, and ecosystem damage" (Klimas 2018, 211).

In South Africa, for example, mining operations have been implicated in acid water seepage, contaminating aquifers and rivers, as well as the release of airborne pollutants, such as asbestos dust, near population centers, causing lung cancer, asbestiosis, and mesothelioma (Knox 2015, 123). Similar harmful impacts to both the environment and people have been noted in the DRC, which holds three-quarters of the world's cobalt reserves and ranks first in industrial diamonds, second in iron, third in pyrochlore, fourth in copper, fifth in coltan, and eighth in cassiterite (Muhigirwa 2015, $35)$. Given the magnitude of mining activity there, Minani's chapter observes that environmental impacts in the DRC have been significant and varied, including deforestation, land degradation, and contamination of air and water. Likewise, in Peru, the gold industry has subjected miners to mercury exposure and poisoning, polluted waterways, and poisoned local communities who consume contaminated fish (Lemke 2016). In Honduras, Bishop Santos Villeda (2018) worries about the method of open-cut mining for gold, whereby foreign companies "use cyanide, which contaminates the ground, the air, and the water but gives them [these companies] great profits because it separates $97 \%$ of the gold particles" (92). Similarly, uranium mining in the United States exposed the Navajo people to radiation poisoning, including through contaminated drinking water that caused birth defects (Arnold 2014). 
Some of these examples of harms both to people, especially indigenous and tribal peoples, and to the environment may be intentional. Indeed, some deleterious consequences appear to be direct and immediate. Others, though, may be the sort of "slow violence" identified by Rob Nixon (2011). These "ecological ripple effects," as Michael Schmitt (1997) calls them, do violence to and through ecosystemic relations. In this vein, Cynthia Moe-Lobeda (2013) details the structural violence of human institutions and systems, such as the inequitable distribution of power and privilege, that degrades, dehumanizes, injures, and kills persons by limiting or preventing their access to life necessities (72-78). As the Catholic Bishops of Appalachia (1975) observed, efforts to address environmental degradation in poor mining communities involve "a struggle against violence-against institutional violence-which sometimes subtly, sometimes brutally, attacks human dignity and life" (21). Indeed, exploitation and corruption are frequently associated with mining companies, especially foreign ones, and governments.

Significantly, conflictual, martial language (e.g., "violence," “attacks") is frequently employed by activists and religious leaders to refer critically to the harms resulting from mining, which brings us back to how extracting minerals invariably involves forcibly removing them and imposing negative consequences on the environment and on people. After detailing the harmful effects of gold mining on Mt. Diwata in the southern Philippines, including the mine tailings containing mercury that poison the Agusan River, along with the fish in these waters and the people that eat them, Randy J.C. Odchigue (2018) writes, "Taken together, these risks present $a$ clear and present danger to the fragile ecosystem and the human community of the Agusan Marsh" (254, italics mine). In other words, mining there poses a grave and imminent threat both to the environment and to people. Similarly, in Brazil, Peter Hughes (2018) speaks of the need "to protect the rainforest" and the "urgent shared responsibility to protect life on the planet from increased global warming," even as he confesses "that we are losing the battle" (98-99). In this volume, Gaspar's chapter cites a 2019 document from the Philippine bishops that describes mining as a threat to the survival of the rural poor. Such wording (e.g., "clear and present danger," "to protect," "losing the battle," "threat to survival") further indicates the link between mining and conflict.

Pope Francis, as did his predecessors John Paul II (1990) and Benedict XVI (2010), also often makes use of martial language to describe the current climate and related environmental crises. In his homily on the feast of Saint Francis on October 4, 2013, Pope Francis (2013b) emphasized that God created our world "to be a place where harmony and peace can flourish," entailing a moral duty for us humans to "respect creation" and to "respect each human being" instead of being "instruments of destruction" of the environment and of human persons in "armed conflicts which cover the earth with blood" (n.p.). Likewise, in his first apostolic exhortation, Evangelii Gaudium, Pope Francis (2013a) expressed concern for vulnerable 
people whose lives are at risk and for "other weak and defenceless beings"-indeed, "creation as a whole"-threatened by destructive human activities motivated by "economic interests or indiscriminate exploitation" $(\$ 215)$. Although it is not explicitly mentioned, Pope Francis's lamentations about species extinction and desertification resulting from such harmful activities obviously echoes the above complaints about the baleful effects of natural resource extraction.

Moreover, in Laudato Si', Francis (2015) emphasizes the link between conflict, or violence, and the harmful consequences for both planet and people. "The violence present in our hearts, wounded by sin," he writes, "is also reflected in the symptoms of sickness evident in the soil, in the water, in the air and in all forms of life" $(\mathbb{2})$. Also, since humans are not separate from, but are part of nature, the violence that we inflict upon nature is also an attack on ourselves, especially the poor and marginalized who are most

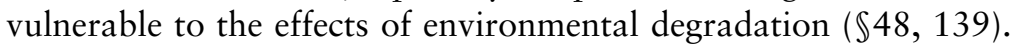

In addition, the pope alludes to "resource wars" due to environmental degradation and natural resource shortages; "it is foreseeable," he warns, "that, once certain resources have been depleted, the scene will be set for new wars" $(\$ 57,48)$. Not only do these actual conflicts harm both the environment and people, so too does ecological destruction impact the poor and "excluded" in ways that they are "treated merely as collateral damage" $(\$ 49$, italics original). Here we see another invocation of terminology usually found in reference to conflict and war.

Mining is explicitly mentioned a handful of times in Laudato Si'. As in some of the examples earlier in Africa, Latin America, and the Philippines, the pope mentions that mercury pollution from gold mining and sulfur dioxide pollution from copper mining have "caused harm locally" $(\mathbb{S 1})$. He also notes how underground water sources are "threatened" by pollution that is produced, and rivers, lakes, and seas are contaminated by chemicals that are used, in "certain mining ... activities," especially in nations without sufficient governmental regulations $(\$ 29)$. Francis also decries the displacement of indigenous peoples and their communities "to make room for... mining projects which are undertaken without regard for the degradation of

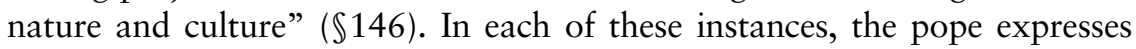
concern for the environment and people, both of which are harmed by the activity of mining. His references to the threats posed by mining and its effects, including the removal of native populations from their homelands, call to mind, furthermore, the inextricable link between extraction and force.

Indeed, Francis makes precisely this point when he explicitly uses the word "extract" in his diagnosis of the conflictual relationship between humankind and nature.

Men and women have constantly intervened in nature, but for a long time this meant being in tune with and respecting the possibilities offered by the things themselves. It was a matter of receiving what 
nature itself allowed, as if from its own hand. Now, by contrast, we are the ones to lay our hands on things, attempting to extract everything possible from them while frequently ignoring or forgetting the reality in front of us. Human beings and material objects no longer extend a friendly hand to one another; the relationship has become confrontational. (\$106, italics mine).

The italicized words all could be used to describe uses of force. Francis clearly acknowledges that since ancient times humans have "intervened in nature," but he does not call for the absolute prohibition of such activities-as long as they are in harmony with, and respectful of, the environment. As the pope puts it, humans were receptive to what nature provided; they did not take or forcibly remove something from nature. His account, however, seems a bit out of sync with his initial use of the words "intervened in nature," unless perhaps by that he means something like "worked with" or "channeled," either of which would presumably be unconfrontational and nonforceful. Is the pope suggesting a complete return to the "in tune with" nature approach of intervening that was characteristic of earlier cultures and of indigenous populations today? If so, would this entail that mining should be abolished altogether?

To be sure, some activists and religious leaders seem to oppose mining absolutely, viewing it as inextricably harmful and violent, akin to how some also reject, if they are absolute pacifists, all other uses of force as immoral. For them, all mining, apparently, is deemed unjust. When pacifist Leo Tolstoy was asked about whether there is a difference between a terrorist's use of armed force and that by a police officer, he replied that the difference is as much as between cat and dog feces-adding that he doesn't like "the smell of either one or the other" (Simmons 1946, 651). So too does Hughes (2018) highlight "the withering verdict of Felipe Huamán Poma de Ayala, the first indigenous writer of the colonial period, who named mines and mining el estiércol del diablo: the devil's excrement!" (103). This absolutist approach is best exemplified in the leading role that the Catholic Church played in El Salvador's decision to ban metallic mining. However, given Francis's endorsement in Laudato Si' of some degree of intervention in nature, and his subsequent remarks at a meeting called "Mining for the Common Good" (2019), an absolute condemnation and prohibition of mining in all cases is not what he is calling for.

Still, as Knox (2015) posits, "It is difficult to think of any mining activity that actually enhances or even protects the integrity or biological diversity of natural systems" (124). Although the extraction of mineral resources provides beneficial goods, such as those that are part of the composition of my laptop computer that I am using right now, the process of mining itself, along with the litany of harmful consequences noted above, not only confronts but forces damage upon the immediate environment and the persons working there, and its deleterious effects ripple throughout the adjacent 


\section{2}

ecosystems and human communities. It also appears unlikely that mining can be conducted absent any harmful consequences at all. Knox observes, "Mining is an inherently dangerous activity" (125). It involves explosives, heavy machinery, and, as we have seen, industrial-strength chemicals. Although it may fail to enhance or protect the integrity of nature, mining provides people with goods-not only luxuries such as diamonds but also "needs" such as the cobalt that is used in lithium batteries and aircraft engine parts-while concurrently it damages or, at best, poses a risk of harm to the environment and to people. Plus, the goods that mining produces are inequitably distributed. To be sure, that our actions result in harms as well as benefits, evils as well as goods, is the case with many, if not all, human activities.

As Joseph A. Selling (2016) observes, there is always present in any human action an "interplay of good and evil," with the latter being not something neutral but "understood as anything that threatens, harms, or diminishes" human persons and, therefore, "should be avoided and minimized as much as possible" (191). Because I strongly doubt that there is going to be a full stop to mining in the foreseeable future, its harms cannot be completely avoided, but should be minimized. In the words of William George (2019), I am "asking not whether mining should be taken off the table, but rather how best to proceed in a manner that is not only economically and technologically feasible but also ecologically responsible and sustainable" (170). Thus, I propose an ethics of extraction that includes a just mining theory with justice as the thread running through moral criteria encompassed under three categories: jus ad extractionem, jus in extractione, and jus post extractionem. Before doing so, however, I need to explain a bit more the reasons for my use of terminology echoing that of just war theory.

\section{An ethic behind and beyond just war}

Standard approaches to ethics are usually classified as deontological, teleological (or utilitarian), or virtue theories. But there are also approaches to ethics that incorporate, or integrate, the strong points of these theories while recognizing their weaknesses. Steffen's (2012) work on a "hybrid ethic" that is "behind" and "beyond" just war thinking offers a helpful way of pursuing an ethics of extraction and a just mining theory. This ethic is grounded in the human capacity to reason and, therefore, is meaningful or persuasive not only to Catholics but to people of good will. Historically, it has been referred to as "natural law" (x)..$^{2}$ As such, it is useful for public deliberation on moral issues, including the various forms of the use of force. Just war thinking is an expression and application of this hybrid ethic.

Importantly, this ethic is not meant to either rationalize or make easier the recourse to force, although that admittedly has often been the case 
through the misuse and abuse of just war theory by self-interested governments and nations; rather, it is intended to provide "a more vigorous public conversation where challenges are issued to-and through-the moral justification process itself" (Steffen 2012, xii). Steffen emphasizes that his effort to "extract the natural law-based and just war-related ethic" provides a framework for moral reflection and criteria for right action applicable to any issue, ranging from war to deception, from abortion to environmental protection $(15,17)$. Accordingly, the ethic offers "a system of guidance for deliberating, analyzing, and prescribing action that is good, right, and fitting," including "normative moral action guides" for gauging and measuring human activity $(33,37)$.

The initial premise of this hybrid ethic behind and beyond just war is that human persons affirm a just peace, which is not merely the absence of conflict or violence, which is a negative form of peace, but the more positive flourishing of harmonious relationships with one another and nature. In the Bible, the Hebrew word shalom refers to this just peace. Shalom is "a deep and all-embracing reality," which is not "simply the absence of violence," but a more positive and reconciling vision (Wirzba 2012, 66). Likewise, for Andean and Amazonian people in Bolivia, the indigenous concept of vivir bien, or "living well," means "a harmonic relationship between humans and nature" (Martins 2020, 131). Steffen (2012) presumes "as a given that reasonable persons of goodwill would prefer to resolve conflicts justly and without resorting to war or any use of force whatsoever if that is possible to do" (26). For Steffen, this is the "moral presumption" against the use of force (44-45), about which Lisa Sowle Cahill writes, "In my view, a presumption against violence ... is necessary to Christian social ethics" (Cahill 2019, 31). Upon this fundamental premise, Steffen (2012) adds that "practical reasonableness necessarily imposes constraints on the use of force" which must be directed "to the rational and good end of peace" (43).

While Steffen (2012), like me, views just war thinking as applicable to issues beyond the use of force, he holds, as do I, that moral deliberations about "the prospective use of force inevitably involve the content of just war thinking" (21). On the relevance of just war reasoning to other moral issues, Steffen devotes attention to physician-assisted suicide, the withholding or withdrawing of medical treatment for severely disabled newborn infants, the death penalty and the criminal justice system, and abortion. Other ethicists have done so, too. In an essay on moral issues in biotechnology and genetics, Cahill (2005) examines the ethics of stem cell research, noting that "as in the case of many social issues, 'inaction' is not an option." Indeed, similarly to what I am calling for with mining, Cahill writes regarding embryonic stem cell research: "The task is therefore not to decide 'prospectively' whether it is a good idea, but to subject it to moral guidance and restraints, acknowledging its potential for beneficial outcomes while limiting the social damage and moral compromises it involves" (231). This looks quite similar, too, to 
what Steffen has been proposing. Thus, unsurprisingly, Cahill turns to just war thinking and to its criteria-which "can be used to discourage and restrain a practice without necessarily drawing an incontrovertible line against it"-to address the moral question of embryonic stem cell research (231, 232-35; see also Lauritzen 2001, 20-23).

Steffen (2012) also considers moral questions surrounding nonviolent resistance (e.g., boycotts, demonstrations, sit-ins) and how just war reasoning and criteria are implicitly exhibited in the thought and actions of Gandhi and Martin Luther King, Jr. Even their nonviolent resistance was a use of force, perhaps even coercive force, which required justification as well as measured application (51-72). ${ }^{3}$ Although Steffen does not mention it, similar just-war analyses of nonviolent force were provided by the influential ethicists James Childress (1971) and Paul Ramsey (1961) over half a century ago. While not always seeing eye to eye on moral methods, Childress and Ramsey wrote extensively on questions both in just war theory and in bioethics (McCarty 2018). Less noted is their attention to nonviolent resistance and protest, and their agreement that just war thinking should be applied to such actions. A similar claim has been made by Maryann Cusimano Love (2010) about her "just peace principles," which she regards as resembling just war principles and as implied in just war thinking (56-57). For his part, Childress (1971) noted about civil disobedience:

The "just war doctrine" offers a set of considerations for determining when war is justified, and analogous criteria must be employed in determining when civil disobedience is justified, although perhaps it is more accurate to suggest that civil disobedience is subject to the same general demands of morality as any other action rather than that it is illuminated by just war criteria. However that may be, certainly the appropriate criteria for evaluating civil disobedience coincide to a great extent with traditional just war criteria such as just cause, good motives and intentions, exhaustion of normal procedures for resolving disputes, reasonable prospect for success, due proportion between probable good and bad consequences, and right means. (204)

I think this insight concerning nonviolent force is significant. Cahill (2019), too, notes that both armed force and nonviolence involve moral dilemmas, ambiguities, and messiness. Not only are there moral costs that result from the use of violent force, so too "the renunciation of violence is not without its own human and moral price" (323). Decisions and actions-including when morally justifiable- "can still have morally evil dimensions, not just unfortunate and regrettable ones" (126, italics original). This is precisely the point made by Selling about the "interplay between good and evil" in human actions and the moral requirement that any evil ought to be avoided, if possible, or at least minimized. 
Steffen (2012) also alludes to the applicability of the just war ethic to policing, an issue about which I have written extensively (41; Winright 2020). In most nations the police are authorized to use force, including lethal force, so an analogous application of the moral reasoning and criteria of just war theory to guide a police officer's decision to use force and to moderate its performance makes sense. As Irish moral theologian Enda McDonagh (1980) has written, "Accepting, in common with the majority of Christians past and present, the need for the violence of restraint in society, one is operating with criteria similar to those of the just war" $(71)^{4}$ That the just war ethic is most applicable to the use of armed, and even unarmed, force is a point that has been made consistently by a range of Catholic and Protestant ethicists. Hence, it makes sense to extend this ethic to the use of force in mining. It is to this exercise of moral imagination and analogical interpretation of just war thinking and criteria to the extraction of mineral resources that I shall now turn.

\section{A just mining framework with action guiding criteria}

Steffen (2012) labels the criteria of just war thinking "action guides ... not intended to rationalize war" but to "impose restraint, insisting that force be used only in a way that is proportionate to the end of addressing injustice and restoring peace" (40). These criteria, or principles, traditionally fall under two categories, jus ad bellum and jus in bello. In recent years, a third category, jus post bellum, has gained traction, although its criteria emerge from taking seriously the obligations of the criterion of right intent-that is, the establishment of a just peace-that serves as the unifying thread holding together all the categories and their criteria (Bell, Jr. 2009; Capizzi 2015; Allman and Winright 2010; 2012). Before constructing a set of analogous just mining criteria, these just war categories and principles need to be delineated.

Depending on the author, the number of criteria varies. Steffen (2012) identifies nine, and so do the US Catholic bishops (1983), although there are slight differences in their respective lists $(22 ; \mathbb{\$} 84-110)$. The Catechism of the Catholic Church (1993) refers to "the traditional elements enumerated in what is called the 'just war' doctrine," but compared to Steffen and the US bishops, it mentions half as many "strict conditions for legitimate defense by military force [which] require rigorous consideration" (no. 2309). I collate the criteria from these sources in what follows.

The first main set of criteria in just war theory is known as jus ad bellum, which includes several criteria, all of which ought to be satisfied prior to embarking upon war. These principles are concerned with why and when going to war is justified. The first criterion is just cause, and it deals specifically with the why aspect of going to war and using armed force. A just war is undertaken in response to serious injustice, such as an act of aggression or an attack. Both the Catechism of the Catholic Church and the 
Compendium of the Social Doctrine of the Church underscore the right and the duty of nations to use force of arms to protect, under the rubric of "legitimate defense," their own citizens and innocent victims in other countries who are unable to defend themselves (Pontifical Council for Justice and Peace 2004, $\$ 500,504)$. The second criterion is legitimate authority. Only duly appointed political authorities who bear responsibility for protecting the common good may declare and wage war. In modern democracies with representative governments, the decision to go to war does not fall on the shoulders of only one person. The third criterion, right intent, "means pursuit of peace and reconciliation, including avoiding unnecessarily destructive acts or imposing unreasonable conditions" (National Conference of Catholic Bishops 1983, \$95). Ultimately, the goal is to restore order, which means setting in motion necessary conditions for establishing a just peace for all who are involved and impacted. This is the telos of just war, which thereby "requires placing just war theory within the larger framework of peacemaking" (Baer and Capizzi 2006, 170). On the fourth criterion, as the Catechism (1993) puts it, "there must be serious prospects of success." There must be a reasonable hope of winning the war and achieving the aim of restoring a just peace. The fifth criterion is last resort. As the Catechism stipulates, "all other means of putting an end to [conflict] must have been shown to be impractical or ineffective" (no. 2309). The sixth criterion, proportionality, weighs the evils associated with going to war; these evils must not be greater than the already-present evils that political authorities are seeking to prevent or stop. Proportionality assesses whether going to war will result in more harm, damage, and costs than any good that might be achieved.

The second major category of criteria for just war is jus in bello, which is concerned with how the war is conducted once hostilities have begun. These criteria gauge the means employed, including weapons, tactics, and targeting. These criteria restrain and limit the use of force. The first criterion within jus in bello is discrimination, or noncombatant immunity. Militaries are supposed to discriminate, or distinguish, between combatants and non-combatants. Moreover, certain places, such as hospitals, schools, and sacred buildings, should not be targeted. The other side of the coin, however, is that some unintentional injuries and deaths of civilians (and damage to non-military property) may be permitted and excused under the euphemism of "collateral damage." At play in this distinction is the principle of double effect, which recognizes that there are multiple effectsgood and evil-from an action (Cavanaugh 2006). As long as the harmful consequences, although foreseen, are not intended, as long as these harmful consequences are not the means to the end that is sought, and as long as these harmful consequences do not outweigh the good results, then the use of force may be considered just. The second criterion within jus in bello is proportionality, which considers on a micro level the fittingness of the actual use of force during war rather than the more macro considerations 
associated with the war itself. Militaries must use only the amount of force necessary, and not excessive force, to achieve their objective. One ought not to use a sledgehammer to swat a mosquito on her neighbor's forehead. That would be excessive, disproportionate force.

The third category of criteria is jus post bellum, which provides a litmus test for the right intention of establishing a just peace for all at war's end (Allman and Winright 2010; Stahn and Kleffner 2008). Because this is a developing area in just war theory, the principles and expectations vary from author to author. For a state or military force that was justified in going to war and was just in its conduct during that war, justice still entails responsibilities after the shooting stops. These include restorative justice, compensation, security and public safety, economic recovery, and environmental cleanup. Such expectations are directed toward the establishment of a just peace, minimizing the likelihood of rekindled conflict.

What might it look like were we to convert or translate these just war criteria into just mining criteria? Again, what I have in mind is akin to the concrete "action guiding principles" of "protect, respect and remedy" that the United Nations Human Rights Office of the High Commissioner (2014) has provided for governments and companies to facilitate the development of consonant policies, rules, and processes. Like just war theory, just mining theory has criteria, or action guides, fitting under three categories: jus ad extractionem, jus in extractione, and jus post extractionem.

For the category of jus ad extractionem, which refers to the justified commencement of mining, the first criterion, just cause, points to the need for the minerals to be mined and the necessity of mining to acquire them. Because the beginning presumption is against the use of force, which includes the use of force in mining that harms the natural environment and human communities, the first criterion requires that the goods provided by the minerals must really be human needs that justify the use of force that harms the environment and risks the well-being of miners and nearby communities. ${ }^{5}$ The theological basis for this initial presumption is articulated by Ferdinand Muhigirwa (2015), who writes, "As a gift of God, all creation and the environment must be safeguarded and protected against harm and adverse environmental impacts that affect the [sic] nature, air, water, forests, wildlife, and the ecosystem" (36). If anything, given the "clear and present danger to the fragile ecosystem and the human community," about which Odchigue (2018) warns, for example, "in the Agusan Marsh" (254), there is more just cause to defend ecosystems and human communities against the harmful threats posed by mining. Therefore, the bar is high for there to be just cause for mineral extraction. In addition, just cause entails that we ask the question about who really benefits from mining, because as Knox (2015) warns, echoes of colonialism and privilege would not constitute just causes for mining (121).

Regarding the second criterion within jus ad extractionem, just authority, part of the problem with mining, as noted by Muhigirwa (2015), is the 
"weakness of the state's regulatory powers" (36). Odchigue (2018) similarly notes that in the Philippines "there appears to be a failure of government agencies to implement regulatory policies for small- and large-scale mining" (255). Knox (2015) adds that the state has a duty "to protect private ownership, which is a human right, but at the same time to ensure that the exercise of this right does not force some to remain in poverty" (122). And in this book, Elias Opongo analyzes the way poor regulation of mining in Eastern Africa can specifically impact conflict by failing to engender sustainable national development. All of these words of caution and recommendation imply more democratic and representative participation in the decision-making processes related to mining-including governments and local community members-so that mining corporations, with their governing boards and executives, are not making decisions alone that impact the lives of others.

The third criterion, right intent, is supposed to be the establishment of a just peace for all. The US bishops (1983) extend this criterion to encompass nature, too: " $[\mathrm{T}]$ rue peace implie[s] the restoration of the right order not just among peoples, but within all of creation” (\$32). As Santos Villeda (2018) notes, drawing from the Compendium of the Social Doctrine of the Church, there is a fundamental rule about "the intervention of the human being in nature [which] should be governed by respect for other persons and their rights as well as respect toward other living creatures" (94; Pontifical Council for Justice and Peace 2004, $\$ 463$ ). Such respect for all entails giving due attention to their safety over against the dangerous harms that may accompany and result from the force of mining. As Santos Villeda (2018) reminds us, security should not only be provided for the companies but also for the people (93). Right intent will, moreover, spill over into the other categories and criteria of just mining.

The fourth criterion, the probability of success, should take into consideration not only the likelihood of acquiring resources through mining, but also the prospects for doing so in a way that minimizes harm to the environment and people, as well as its odds of benefitting all involved, such as by creating integral human development and preserving cultural and environmental heritages. As such, this criterion is related to other criteria, such as proportionality, and serves as a reminder that for an action using force, such as mining, to be considered morally justified, all the criteria-not only one or some-must be satisfied.

The jus ad extractionem criterion of last resort asks whether other reasonable and feasible means of obtaining mineral resources have been first attempted and exhausted. Or, have other alternative sources of what a particular mineral provides been seriously explored? Another way of getting at this criterion is to see it as connected to the ecological "precautionary principle," which says to err on the side of precaution, to make sure we have explored other ways of moving forward that avoid or minimize the negative effects of the present course of action that is under consideration 
(Brinkman 2013, 207). Because the dangerous "risks [of mining] are all known," Knox (2015) advises that "reasonable precautions... [should] be in place" (125). One pertinent practice to consider here is recycling, which, as the chapter by Holden and Montevecchio notes, can greatly reduce the need for new mining even if it would mean lower corporate profits and higher consumer costs.

For the jus ad extractionem criterion of proportionality, the ecological concept of sustainability seems apt. On sustainability, Christiana Zenner and Andrea Vicini (2015) begin with the 1987 report of the Bruntdland Commission, Our Common Future, which linked the environmental and social impacts of economic development, and called for sustainable development to mean meeting people's needs today while protecting sufficient natural resources for future generations (1). ${ }^{6}$ As they note, sustainability is related to "the norm of justice," which entails "fairness to future generations as well as respect for ecosystems and the earth processes on which all forms of life (including but not limited to humans) depend" (3). With regard to mining, Knox (2015) thinks the "concept of 'sustainable mining' presents an inherent paradox," since these natural resources are "neither in infinite supply nor constantly being renewed" (117). Weighing justice in these ways is reflective of using proportionality.

In the second category, jus in extractione, with its two criteria of discrimination and proportionality, the focus turns to the actual means employed in the mining operations. Discrimination would rule out direct, intentional attacks on that which is necessary for human life, such as water, food, and homes. As with surgery in medical ethics and with surgical strikes in just war ethics, extraction ethics expects that the intended damage from the use of force by mining be immediately directed to the area mined. That is, mining companies and workers must discriminate, or draw a distinction, between the plot of earth to be mined and the surrounding area. They should also use the most fitting, least harmful means of mining, thereby minimizing dangers and risks. The impacts on necessities such as water should also be taken into account in assessing proportionality. The fact that the national ban on mining in El Salvador was based on protecting water is an example of how the norm of discrimination and proportionality might apply. Moreover, any foreseeable harms to the wider ecological systems and human communities must be avoided or curtailed as much as possible. Under these circumstances any collateral damage to the wider environment and population might perhaps be excusable, employing the principle of double effect, as long as the harmful consequences are not disproportionate to the benefits from the mining for the company, the consumer elsewhere, and the community there. These criteria for jus in extractione should also take into account the future considerations that arise with sustainability. There should also be just remuneration and compensation for workers (Knox 2015, 125).

The third category of just mining criteria, jus post extractionem, requires that mining companies take responsibility for what they have done to the 
mining site and its environs, as well as the ongoing consequences of the mining conducted there. Santos Villeda (2018) urges that "it is necessary to evaluate the long-term environmental cost of extractive activities" (95). So too does Knox (2015) anticipate the "costly cleanup" of environmental damage (120). Not only should toxic waste be removed, perhaps trees and flora should be planted. For affected human communities, adequate health care and financial compensation should be provided and the land should be restored for new development activities or other uses. Post-mining expectations such as these help ensure that the pre-mining right intent has been sincerely implemented throughout all phases.

\section{Conclusion: extraction ethics and integral peace}

James M. Gustafson (1996) identified four types of moral discourse: ethical, policy, prophetic, and narrative. This chapter intentionally exemplifies the first two types. The task of the ethical mode is to provide guidance for deciding "how one ought to act in particular circumstances" by referring to concepts such as rights and duties, as well as norms like justice (39). The task of the policy mode is to assess practices, institutions, and action guides for persons within social institutions such as governments and corporations. This mode takes seriously limitations and conflicts within concrete situations as well as the need for compromise and accommodation. By attempting to communicate persuasively to business and governmental audiences, by giving attention to the interplay of goods and inevitable evils accompanying mining as a use of force, and by attempting to limit these evils while stopping short of the prohibition of mineral extraction altogether, my just mining framework and criteria also are consonant with the ethical and policy discourses.

Perhaps more absolute stances against the use of force-whether in war or mining-fit within Gustafson's other two types of moral discourse. The prophetic mode attempts to widen the scope of vision and reorient worldviews. As such, it tends to be "more general than ethical discourse" (Gustafson 1996, 41). It also employs narratives sometimes, especially from Scripture, to indict injustice and to inspire hope for a just peace. The narrative type serves to shape the character of persons and the ethos of communities. It tends to be less universal, its audience more distinctively religious. It also tends not to provide concrete answers to complex moral problems.

The hybrid ethic that I am suggesting can include all four of these types of moral discourse. Because this essay's primary audience is mining professionals and political authorities, I have mostly employed the ethical and policy discourses. That is not to say that this just mining framework cannot be useful for religious leaders and activists, including those who are more, if not absolutely, opposed to mining. For them, I would suggest that this just mining framework and its principles be viewed as what a number of 
Mennonite ethicists have called "middle axioms," which call "other people or institutions to live up to their own stated moral principles, highest ideals, or long-term enlightened self-interests without endorsing all of the assumptions behind others' ethical systems" (Schlabach 2019, 219). The concrete action guides I have suggested can be appealed to by anyone to hold those who do mining accountable to justice.

Daniel Cowdin (2008) observes that Catholic environmental ethics has "difficulties... at the level of specific principles and norms...mediating between its deeper theological foundations and the specificity of concrete situations" (166). In his view, it "lacks the kind of action-guiding moral traction that is typical of other areas in the Catholic moral tradition," such as just war thinking and bioethics (180-81). This chapter has attempted to suggest these sort of concrete action guides for mining. Extraction ethics entails a just mining framework, consisting of criteria that serve as action guides prior to mining (jus ad extractionem), during mining (jus in extractione), and following mining (jus post extractionem). Adherence to this just mining framework, it is hoped, should mitigate the devastating consequences of mining to the environment and people. In doing so, just mining should, moreover, diminish the likelihood of causing or exacerbating conflict. It should also contribute to "integral peace" (Winright 2016; 2018). Throughout Laudato Si', Pope Francis (2015) uses the word integral, especially when calling for the promotion of an "integral ecology" that recovers "a serene harmony with creation" and "break[s] with the logic of violence, exploitation and selfishness" $(\$ 225,230)$. Francis also uses the term when referring to the need for contributions from an array of disciplines and sources, including science, economics, politics, ethics, and faith (\$137). Here he seems to have in mind not only making connections and interrelating insights from these various sources, but integration, or synthesis (Butkus and Kolmes 2011). Integral peace, I suggest, is the end, or telos, of the hybrid ethic behind and beyond just war thinking, as exemplified in an extraction ethics consisting of a just mining framework.

\section{Notes}

1 Sometimes called "just war tradition" and "just war thinking," I regard "just war theory" as a part of the just war tradition, which includes multiple versions or theories, as well as developments over the years, and all of which are expressions of just war thinking. For more on the language of "presumption," see Winright (2009).

2 This just war mode of reasoning can be found in non-Western and non-Christian cultures as well (Lo and Twiss 2015; Kelsay 1993; 2007).

3 As Steffen acknowledges, this observation about the coerciveness and destructive consequences of nonviolent methods was made by prominent ethicist Reinhold Niebuhr (1932, 241).

4 This interpretation echoes that of Ralph B. Potter (1973, 49-50), Edward A. Malloy (1982, 10, 24), and Paul Ramsey (1968), who argued that the "moral economy" of the just war tradition is "morally if not legally binding upon the use 


\section{Tobias Winright}

of force between nations," and it also "regulates the use of force within political communities, where it is both morally and legally binding" (144).

5 This concern is affirmed in this book by Douglass Cassel, who argues that the end-use of minerals should be a consideration in the ethical analysis of the operation to be undertaken.

6 The Brundtland Commission stated that "sustainable development is development that meets the needs of the present without compromising the ability of future generations to meet their own needs" (United Nations World Commission on Environment and Development 1987, ch. 2, $\mathbb{1}$ ).

\section{References}

Allman, Mark J., and Tobias L. Winright. 2010. After the Smoke Clears: The Just War Tradition and Post War Justice. Maryknoll, NY: Orbis Books.

Allman, Mark J., and Tobias L. Winright. 2012. "Growing Edges of Just War Theory: Jus Ante Bellum, Jus Post Bellum, and Imperfect Justice." Journal of the Society of Christian Ethics 32, no. 2: 173-191. 10.1353/sce.2012.0039.

Arnold, Carrie. 2014. "Once Upon a Mine: The Legacy of Uranium on the Navajo Nation." Environmental Health Perspectives 122, no. 2: A44-A49. 10.1289\%2 Fehp.122-A44.

Baer, Helmut David, and Joseph E. Capizzi. 2006. "Just War Theory and the Problem of International Politics: On the Central Role of Just Intention.” Journal of the Society of Christian Ethics 26, no. 1: 163-175. https://www.jstor.org/ stable/23561502.

Bell, Daniel M., Jr. 2009. Just War as Christian Discipleship: Recentering the Tradition in the Church Rather Than the State. Grand Rapids, MI: Brazos Press. Benedict XVI. 2010. "If You Want to Cultivate Peace, Protect Creation.” World Day of Peace message. January 1, 2010. http://w2.vatican.va/content/benedictxvi/en/messages/peace/documents/hf_ben-xvi_mes_20091208_xliii-world-daypeace.html.

Benedict XVI. 2011. https://www.vatican.va/content/benedict-xvi/en/apost_exhortations/ documents/hf_ben-xvi_exh_20111119_africae-munus.html.

Brinkman, John T. 2013. "Discernment of the Church and the Dynamics of the Climate Change Convention." In Environmental Justice and Climate Change, edited byJame Schaefer and Tobias Winright, 197-214. Lanham, MD: Lexington Books.

Butkus, Russel A., and Steven A. Kolmes. 2011. Environmental Science and Theology in Dialogue. Maryknoll, NY: Orbis Books.

Cahill, Lisa Sowle. 2005. Theological Bioethics: Participation, Justice, and Change. Washington, DC: Georgetown University Press.

Cahill, Lisa Sowle. 2019. Blessed Are the Peacemakers: Pacifism, Just War, and Peacebuilding. Minneapolis: Fortress Press. 10.2307/j.ctv9b2ww5.

Capizzi, Joseph E. 2015. Politics, Justice, and War: Christian Governance and the Ethics of Warfare. Oxford: Oxford University Press. 10.1093/acprof:oso/ 9780198723950.001.0001.

Catechism of the Catholic Church. 1993. Vatican City: Libreria Editrice Vaticana. Catholic Bishops of Appalachia. 1975. This Land Is Home to Me: A Pastoral Letter on Powerlessness in Appalachia by the Catholic Bishops of the Region. Martin, KY: Catholic Committee of Appalachia. 
Cavanaugh, T.A. 2006. Double Effect Reasoning: Doing Good and Avoiding Evil. New York: Oxford University Press. 10.1093/0199272190.001.0001.

Childress, James F. 1971. Civil Disobedience and Political Obligation: A Study in Christian Social Ethics. New Haven, CT: Yale University Press.

Cowden, Daniel. 2008. "Environmental Ethics." Theological Studies 69, no. 1: 164-184. 10.1177\%2F004056390806900109.

Detraz, Nicole. 2015. Environmental Security and Gender. New York: Routledge. $10.4324 / 9781315765037$.

Francis. 2013a. Evangelii Gaudium. http://w2.vatican.va/content/francesco/en/ apost_exhortations/documents/papa-francesco_esortazione-ap_20131124_evangelii-gaudium.html.

Francis. 2013b. "Homily of the Holy Father Francis: Pastoral Visit to Assisi." October 4, 2013. http:/www.vatican.va/holy_father/francesco/homilies/2013/ documents/papa-francesco_20131004_omelia-visita-assisi_en.html.

Francis. 2015. Laudato Si'. http://www.vatican.va/content/francesco/en/encyclicals/ documents/papa-francesco_20150524_enciclica-laudato-si.html.

Francis. 2019. "Address to Participants at the Meeting Promoted by the Dicastery for Promoting Integral Human Development on the Mining Industry." May 3, 2019. http://www.vatican.va/content/francesco/en/speeches/2019/may/documents/ papa-francesco_20190503_incontro-industria-mineraria.html.

George, William P. 2019. Mining Morality: Prospecting for Ethics in a Wounded World. Lanham, MD: Lexington Books.

Gustafson, James M. 1988. Varieties of Moral Discourse: Prophetic, Narrative, Ethical, and Policy. Grand Rapids, MI: Calvin College.

Gustafson, James M. 1996. Intersections: Science, Theology, and Ethics. Cleveland, $\mathrm{OH}$ : Pilgrim Press.

Hughes, Peter. 2018. "The Pan Amazon, Extractive Industries, and the Church." In Fragile World: Ecology and the Church, edited by William T. Cavanaugh, 97-111. Eugene, OR: Cascade Books.

John Paul II. 1990. "Peace with God the Creator, Peace with All of Creation." World Day of Peace Message. January 1, 1990. http://www.vatican.va/holy_ father/john_paul_ii/messages/peace/documents/hf_jp-ii_mes_19891208_xxiiiworld-day-for-peace_en.html.

Kelsay, John. 1993. Islam and War: A Study in Comparative Ethics. Louisville, KY: Westminster/John Knox Press.

Kelsay, John. 2007. Arguing the Just War in Islam. Cambridge, MA: Harvard University Press. 10.2307/j.ctvjz81s7.

Klimas, Christie. 2018. "Christian Christmas Consumption: Ethical Considerations of the Environmental and Social Impacts of Holiday Spending." In Fragile World: Ecology and the Church, edited by William T. Cavanaugh, 210-218. Eugene, OR: Cascade Books.

Knox, Peter. 2015. "Sustainable Mining in South Africa: A Concept in Search of a Theory." In Just Sustainability: Technology, Ecology, and Resource Extraction, edited byChristiana Z. Peppard and Andrea Vicini, 117-130. Maryknoll, NY: Orbis Books. 10.1353/sce.2018.0018.

Koch, Dirk-Jan, and Sara Kinsbergen. 2018. "Exaggerating Unintended Effects? Competing Narratives on the Impact of Conflict Minerals Regulation." Resources Policy 57: 255-263. 10.1016/j.resourpol.2018.03.011. 


\section{Tobias Winright}

Lauritzen, Paul. 2001. "Neither Person nor Property: Embryo Research and the Status of the Early Embryo." America 184, no. 10 (March 26, 2001): 20-23.

Lederach, John Paul. 2003. Little Book of Conflict Transformation: Clear Articulation of the Guiding Principles by a Pioneer in the Field. New York: Good Books.

Lederach, John Paul. 2005. The Moral Imagination: The Art and Soul of Building Peace. New York: Oxford University Press. 10.1093/0195174542. 001.0001.

Lee, Chia-yi. 2018. "Oil and Terrorism: Uncovering the Mechanisms." Journal of Conflict Resolution 62, no. 5: 903-928. 10.1177\%2F0022002716673702.

Lemke, Rebekah Kates. 2016. "The Pull of Peru’s Gold Rush.” CRS.org. December 30, 2016. https://www.crs.org/stories/peru-illegal-gold-mining-climate-change.

Lo, Ping-Cheung, and Sumner B. Twiss, eds. 2015. Chinese Just War Ethics: Origin, Development, and Dissent. London: Routledge. 10.4324/9781315740706.

Love, Maryann Cusimano. 2010. "What Kind of Peace Do We Seek? Emerging Norms of Peacebuilding in Key Political Institutions." In Peacebuilding: Catholic Theology, Ethics, and Praxis, edited byRobert J. Schreiter, R. Scott Appleby, and Gerard F. Powers, 56-91. Maryknoll, NY: Orbis Books.

Lujala, Päivi. 2010. "The Spoils of Nature: Armed Civil Conflict and Rebel Access to Natural Resources." Journal of Peace Research 47, no. 1: 14-28. 10.1177\%2 F0022343309350015.

Malloy, Edward A. 1982. The Ethics of Law Enforcement and Criminal Punishment. Washington, DC: University Press of America.

Martins, Alexandre A. 2020. The Cry of the Poor: Liberation Ethics and Justice in Health Care. Lanham, MD: Lexington Books.

McCarty, Brett. 2018. "Medicine as Just War? The Legacy of James Childress in Christian Ethics." Journal of the Society of Christian Ethics 38, no. 2: 57-74. 10.1353/sce.2018.0033.

McDonagh, Enda. 1980. Church and Politics: From Theology to a Case History of Zimbabwe. Notre Dame, IN: University of Notre Dame Press.

Moe-Lobeda, Cynthia. 2013. Resisting Structural Evil: Love as EcologicalEconomic Vocation. Minneapolis: Fortress Press.

Muhigirwa Rusembuka, Ferdinand. 2015. "Theological Perspectives on Governance in the Mining Sector in the Democratic Republic of Congo." In Just Sustainability: Technology, Ecology, and Resource Extraction, edited by Christiana Z. Peppard and Andrea Vicini, 35-38. Maryknoll, NY: Orbis Books. 10.1353/sce.2018.0018.

National Conference of Catholic Bishops. 1983. The Challenge of Peace: God's Promise, Our Response. Washington, DC: United States Catholic Conference.

Niebuhr, Reinhold. 1932. Moral Man and Immoral Society. New York: Scribner.

Nixon, Rob. 2011. Slow Violence and the Environmentalism of the Poor. Cambridge, MA: Harvard University Press. 10.4159/harvard.9780674061194.

Odchigue, Randy J. C. 2018. "Nurturing Communities, Sustaining Fragile Ecologies." In Fragile World: Ecology and the Church, edited by William T. Cavanaugh, 252-270. Eugene, OR: Cascade Books.

Pontifical Council for Justice and Peace. 2004. Compendium of the Social Doctrine of the Church. Washington, DC: United States Conference of Catholic Bishops, 2004. 
Potter, Ralph B. 1973. War and Moral Discourse. Richmond, VA: John Knox Press.

Ramsey, Paul. 1961. Christian Ethics and the Sit-In. New York: Association Press. Ramsey, Paul. 1968. The Just War: Force and Political Responsibility. New York: Charles Scribner's Sons.

Santos Villeda, Luis Alfonso. 2018. "Extractive Industries, Destructive Industries: The Case of Honduras-A Fragile Country and Devastated Ecology." In Fragile World: Ecology and the Church, edited by William T. Cavanaugh, 91-96. Eugene, OR: Cascade Books.

Schlabach, Gerald W. 2019. A Pilgrim People: Becoming a Catholic Peace Church. Collegeville, MN: Liturgical Press.

Schmitt, Michael. 1997. "Green War: An Assessment of the Environmental Law of International Conflict." Yale Journal of International Law 22: 1-109. https:// digitalcommons.law.yale.edu/yjil/vol22/iss1/2/.

Selling, Joseph A. 2016. Reframing Catholic Theological Ethics. Oxford: Oxford University Press. 10.1093/acprof:oso/9780198767121.001.0001.

Siegel, Shefa. 2013. "The Missing Ethics of Mining." Ethics and International Affairs 27, no. 1. https://www.ethicsandinternationalaffairs.org/2013/the-missing-ethicsof-mining-full-text.

Simmons, Ernest J. 1946. Leo Tolstoy. Boston: Little, Brown and Company.

Stahn, Carsten, and Jann K. Kleffner, eds. 2008. Jus Post Bellum: Towards a Law of Transition from Conflict to Peace. The Hague: TMC Asser Press. 10.1007/ 978-90-6704-719-7.

Steffen, Lloyd. 2012. Ethics and Experience: Moral Theory from Just War to Abortion. Lanham, MD: Rowman \& Littlefield, 2012.

United Nations Human Rights Office of the High Commissioner. 2014. Frequently Asked Questions About the Guiding Principles on Business and Human Rights. Geneva: United Nations. https://www.ohchr.org/documents/publications/faq_ principlesbussinesshr.pdf.

United Nations World Commission on Environment and Development. 1987. Our Common Future: Report of the World Commission on Environment and Development. Oslo: United Nations. https:/sustainabledevelopment.un.org/ content/documents/5987our-common-future.pdf.

Vocabulary.com. n.d. "Extraction.” Accessed April20, 2021. https://www.vocabulary. com/dictionary/extraction.

Winright, Tobias. 1995. "The Perpetrator as Person: Theological Reflections on the Just-War Tradition and the Use of Force by Police." Criminal Justice Ethics 14, no. 2: 37-56. 10.1080/0731129X.1995.9991997.

Winright, Tobias. 2009. "The Liturgy as a Basis for Catholic Identity, Just War Theory, and the Presumption against War." In Catholic Identity and the Laity, edited by Tim Muldoon, 134-151. Maryknoll, NY: Orbis Books.

Winright, Tobias. 2016. "Your 'Just Peace' Reading List." National Catholic Reporter, December 21, 2016. https://www.ncronline.org/books/2017/08/yourjust-peace-reading-list.

Winright, Tobias. 2017. "Peace on Earth, Peace with Earth: Laudato Si' and Integral Peacebuilding." In All Creation Is Connected: Voices in Response to Pope Francis's Encyclical on Ecology, edited by Daniel R. DiLeo, 195-211. Winona, MN: Anselm Academic. 


\section{Tobias Winright}

Winright, Tobias. 2020. Serve and Protect: Selected Essays on Just Policing. Eugene, OR: Cascade Books.

Wirzba, Norman. 2012. "Reconciliation through Christ." In Making Peace with the Land: God's Call to Reconcile with Creation, edited by Fred Bahnson and Norman Wirzba, 61-82. Downers Grove, IL: InterVarsity.

Zenner, Christiana [published as Christiana Z. Peppard], and Andrea Vicini. 2015. "Introduction: On Just Sustainability and Its Challenges." In Just Sustainability: Technology, Ecology, and Resource Extraction, edited by Christiana Z. Peppard and Andrea Vicini, 1-10. Maryknoll, NY: Orbis Books. 10.1353/sce.2018.0018. 